DOI https://doi.org/10.30525/978-9934-26-183-1-25

\title{
ДИНАМІКА ХІМІЧНОГО СКЛАДУ ПИТНИХ ПІДЗЕМНИХ ВОД КОРОСТИШІВСЬКОГО РАЙОНУ ЖИТОМИРСЬКОЇ ОБЛАСТІ
}

\author{
Кошлякова Т. О. \\ кандидат геологічних наук, \\ стариий науковий співробітник відділу геохімї̈ техногенних металів \\ та аналітичної хімії \\ Інститут геохіміі, мінералогії та рудоутворення \\ імені М. П. Семененка Національної академї наук Украӥни \\ м. Київ, Україна
}

На сьогоднішній день постійно зростаючий рівень техногенного забруднення об'єктів навколишнього середовища (грунтів, природних водойм та атмосферного повітря), обумовлюють необхідність проведення постійного моніторингу їх стану. Особливо важливим $є$ встановлення елементного складу питної води та вивчення особливостей його формування на територіях різних країн в зв'язку зі світовою проблемою забезпечення людства якісною та безпечною питною водою, яка $є$ основою життєдіяльності людини. Актуальним $є$ вирішення цих задач і для усіх гідрогеологічних регіонів України, які відрізняються рядом геохімічних особливостей.

У контексті досягнення нетоксичного середовища в рамках Свропейського зеленого курсу (European Green Deal), до якого Україна долучилася у 2020 році, актуальності набувають дослідження, спрямовані на вивчення мінерального складу та вмісту фізіологічно значущих хімічних елементів у питних підземних водах різних регіонів України, особливо тих, що характеризуються високим рівнем техногенного навантаження на підземну гідросферу та/або негативним тенденціями у динаміці показників захворюваності населення. Представлене дослідження присвячене вивченню динаміки зміни хімічного складу питних підземних вод у Коростишівському районі Житомирської області, що, згідно сучасного гідрогеологічного районування України $[1$, с. 7] належить до водоносної системи Українського щита.

Досліджувана територія розташована в північно-західній частині Гідрогеологічної області тріщинних вод Українського щита i характеризується наявністю комплексу переважно піщанистих осадових порід незначної потужності (до 20 м), багатоповерховим заляганням водоносних горизонтів в умовах вільного водообміну. Зразки води зі 
свердловин та криниць відбиралися в межах Коростишівського району Житомирської області, до якого приурочене Коростишівське родовище питних підземних вод. Загалом господарсько-питне i виробничотехнічне водопостачання у самому м. Коростишів здійснюється за рахунок експлуатації водоносних горизонтів у відкладах бучацького регіоярусу еоцену (Р2bč) i в тріщинуватій зоні кристалічних порід та їх кори вивітрювання (PR1). Мешканці довколишніх сіл здебільшого споживають воду з присадибних криниць або свердловин, що експлуатують водоносний горизонт в алювіальних відкладах 1-2 надзаплавних терас верхнього неоплейстоцену (a1-2PIII), та приватних свердловин, пробурених на водоносний горизонт у тріщинуватій зоні кристалічних порід та їх кори вивітрювання (PR1). Варто відмітити, що водозабірна ділянка Коростишівського МКП «Водоканал» розташована в зоні розвантаження підземних вод, де р. Тетерів відіграє роль потужної природної дрени. Крім того, в межах розповсюдження водоносного горизонту в алювіальних відкладах голоцену, поверхневі води $\epsilon$ джерелом формування експлуатаційних запасів підземних вод основного водоносного горизонту у тріщинуватій зоні кристалічних порід і їх кори вивітрювання [2, с. 1].

У комплексі моніторингових досліджень якості підземних вод регіону з метою детального вивчення мікроелементного складу із залученням сучасних, більш чутливих, лабораторних методів, у липні 2020 та у серпні 2021 року авторами було проведено відбір проб зразків води зі свердловин та криниць Коростишівського району Житомирської області, які використовуються місцевим населенням для питного водопостачання. Кожного року відбиралося по 15 зразків води з криниць та по 10 зразків зі свердловин, розташованих на присадибних ділянках приватних будинків. Глибина криниць коливалася в межах 10-15 м, свердловин - 10-20 м.

Результати загального хімічного аналізу, виконаного для відібраних у 2020-2021 рр. зразків води, у порівнянні з гранично допустимими концентраціями (ГДК) згідно Державних санітарних норм та правил «Гігієнічні вимоги до води питної, призначеної для споживання людиною» (ДСанПіН 2.2.4-171-10), представлені у Таблиці 1. 
Таблиця 1

Результати загального хімічного аналізу зразків підземних вод

\begin{tabular}{|c|c|c|c|c|c|}
\hline \multirow{4}{*}{$\begin{array}{c}\text { Показник } \\
\text { хімічного } \\
\text { складу }\end{array}$} & \multicolumn{4}{|c|}{ Вид водозабірної споруди } & \multirow{4}{*}{$\begin{array}{c}\text { ГДК за } \\
\text { ДСанПіН } \\
\text { 2.2.4-171-10 }\end{array}$} \\
\hline & \multicolumn{2}{|c|}{ Криниця } & \multicolumn{2}{|c|}{ Свердловина } & \\
\hline & \multicolumn{4}{|c|}{ Середнс значення } & \\
\hline & 2020 рік & 2021 рік & 2020 рік & 2021 рік & \\
\hline $\mathrm{pH}$ & 6,95 & 6,68 & 7,22 & 7,05 & $6,5-8,5$ \\
\hline Лужність & 1,6 & 2,1 & 4,9 & 5,1 & $\begin{array}{c}\text { не } \\
\text { нормується } \\
\end{array}$ \\
\hline $\begin{array}{l}\text { Жорсткість, } \\
\text { мг-екв/дм }{ }^{3}\end{array}$ & 3,8 & 4,5 & 6,9 & 6,8 & 10 \\
\hline Кальцій, мг/дм & 56,11 & 56,1 & 96,2 & 94,2 & $\begin{array}{c}\text { не } \\
\text { нормується }\end{array}$ \\
\hline Магній, мг/дм³ & 12,16 & 20,7 & 25,54 & 25,5 & $\begin{array}{c}\text { не } \\
\text { нормується }\end{array}$ \\
\hline $\mathrm{HCO}_{3}^{-}$, мг/дм ${ }^{3}$ & 97,6 & 128,1 & 289,9 & 311,1 & $\begin{array}{c}\text { не } \\
\text { нормується } \\
\end{array}$ \\
\hline $\begin{array}{c}\text { Сульфати, } \\
\text { мг/дм }{ }^{3} \\
\end{array}$ & 28,8 & 96,0 & 24 & 72,0 & 500 \\
\hline $\begin{array}{c}\text { Залізо загальне, } \\
\text { мг/дм }{ }^{3}\end{array}$ & 0,03 & 0,04 & 0,05 & 0,07 & 1 \\
\hline Нітрати, мг/дм ${ }^{3}$ & 52,77 & 30,5 & 39,1 & 27,5 & 50 \\
\hline $\begin{array}{c}\text { Хлориди, } \\
\text { мг/дм }\end{array}$ & 42,6 & 48,3 & 39,1 & 49,7 & 350 \\
\hline $\begin{array}{c}\text { Сухий } \\
\text { залишок, г/дм }\end{array}$ & 0,224 & 0,313 & 0,304 & 0,378 & 1,5 \\
\hline $\begin{array}{c}\mathrm{Na}+\mathrm{K} \text { сумарно, } \\
\text { мг-екв/дм }{ }^{3}\end{array}$ & 18,4 & 37,17 & 9,2 & 37,7 & $\begin{array}{c}\text { не } \\
\text { нормується }\end{array}$ \\
\hline
\end{tabular}

Примітка-кількість проб $(\mathrm{N})=25$

Загалом досліджені зразки підземних вод за своїм макроелементним складом відповідають нормативам ДСанПіН 2.2.4-171-10 для питної води 3 колодязів, каптажів та джерел. Виключенням $є$ вміст нітратів, концентрація яких у колодязях станом на 2020 рік перевищувала ГДК.

Авторами було проаналізовано динаміку змін таких показників хімічного складу досліджуваних підземних вод: загальна мінералізація, вміст іонів $\mathrm{Ca}^{2+}, \mathrm{Mg}^{2+}, \mathrm{SO}_{4}{ }^{2-}$ та $\mathrm{Cl}^{-}$. Період спостережень за коливаннями концентрацій вказаних показників охоплював березень 2017 - грудень 2019 рр. [3, С. 60].

Відомо, що інтенсивність водовідбору, яка визначає гідродинамічні умови взаємодії поверхневих та підземних вод, $є$ одним 3 головних чинників зміни їх хімічного складу. Було виявлено значиму кореляцію 
між концентраціями $\mathrm{Mg}^{2+}, \mathrm{SO}_{4}^{2-}, \mathrm{Cl}^{-}$та їх нормованими показниками за величиною водовідбору. Коефіцієнти кореляції (К кор $)$ склали, відповідно: для $\mathrm{Mg}^{2+}-\mathrm{K}_{\text {кор }}=0,82$; для $\mathrm{SO}_{4}{ }^{2-}-\mathrm{K}_{\text {кор }}=0,63$; для $\mathrm{Cl}^{-}-\mathrm{K}_{\text {кор }}=$ 0,76 . 3 метою встановлення закономірностей зміни досліджуваних показників хімічного складу підземних вод у зв'язку з водовідбором, було побудовано графіки коливань нормованих показників за період 2017-2019 рр. (рис. 1).

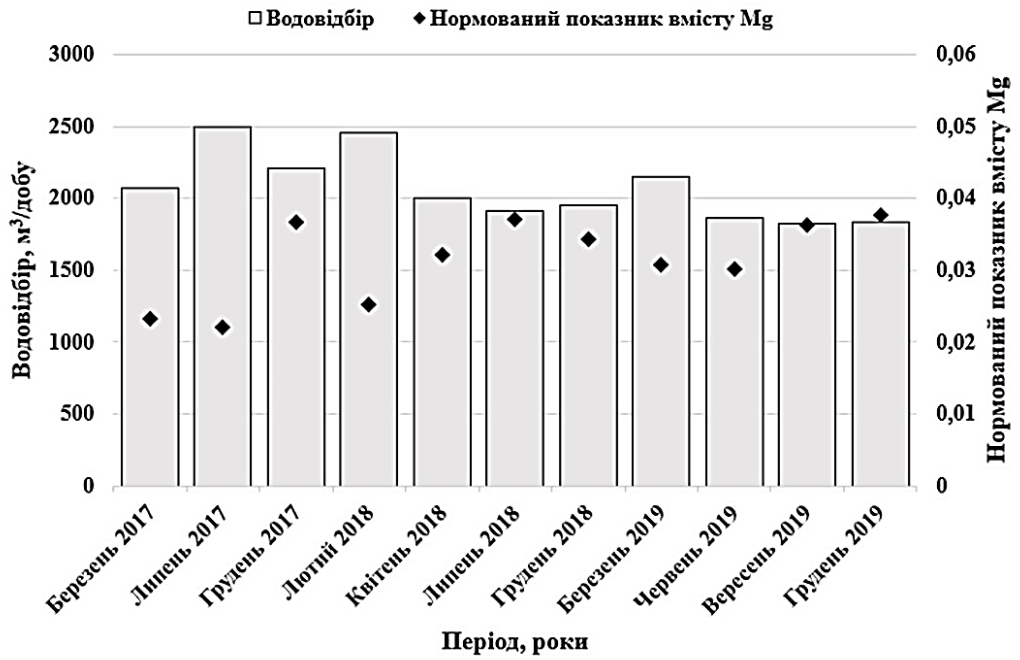

Рис. 1. Нормовані показники вмісту Мg та водовідбору з водоносного горизонту у тріщинуватій зоні кристалічних порід та їх кори вивітрювання в період 2017-2019 рр.

У результаті проведеного дослідження були отримані наступні висновки:

1. Зразки підземних вод з обстежених водоносних горизонтів за своїм макроелементним складом відповідають нормативам ДСанПіН 2.2.4171-10 для питної води з колодязів, каптажів та джерел. Виключенням $\epsilon$ вміст нітратів, концентрація яких у криницях станом на 2020 рік незначною мірою перевищувала ГДК $(52,77$ мг/дм³ у порівнянні 3 нормативом у 50 мг/дм³ $)$.

2. Виявлено високу позитивну кореляцію між концентраціями $\mathrm{Mg}^{2+}$, $\mathrm{SO}_{4}^{2-}, \mathrm{Cl}^{-}$та їх нормованими показниками за величиною водовідбору. 
Коефіцієнти кореляції ( $\left.\mathrm{K}_{\text {кор }}\right)$ склали, відповідно, для $\mathrm{Mg}^{2+}-\mathrm{K}_{\text {кор }}=0,82$; для $\mathrm{SO}_{4}{ }^{2-}-\mathrm{K}_{\text {кор }}=0,63$; для $\mathrm{Cl}^{-}-\mathrm{K}_{\text {кор }}=0,76$. Отримані результати показали, що при збільшенні водовідбору з водоносного горизонту у тріщинуватій зоні кристалічних порід i ix кори вивітрювання підвищується вміст мінеральних речовин, що свідчить про істотну роль техногенного чинника при формуванні хімічного складу досліджуваних підземних вод.

\section{Література:}

1. Шестопалов В.М., Лютий Г.Г., Саніна І.В. Сучасні підходи до гідрогеологічного районування України. Мінеральні ресурси Украӥни. № 2. 2019. C. 3-12. https://doi.org/10.31996/mru.2019.2.3-12

2. Koshliakova, T., Kuraieva, I., Koshliakov, O. Study of microelement composition of potable groundwater in Korostyshiv district of Zhytomyr region in hydrogeochemical monitoring system. Abstracts of XIV International Scientific Conference «Monitoring of Geological Processes and Ecological Condition of the Environment» (10-13 November 2020, Kyiv, Ukraine). 2020. 4 p. https://doi.org/10.3997/2214-4609.202056020

3. Гребенюк, М., Цимбал, Д. Повторна геолого-економічна оцінка експлуатаційних запасів Коростишівського родовища питних підземних вод по свердловинах Коростишівського МКП «Водоканал» в м. Коростишів Житомирської області (підрахунок запасів станом на 01.01.2020). Науковий звіт. Київ : ТОВ «Гео Пошук». 2020. 242 с. 